\title{
PENGEMBANGAN UNIT PROSES PRODUKSI DAN KEMASAN PRODUK OLAHAN BERBASIS RUMPUT LAUT UNTUK USAHA MIKRO PEMBUATAN DODOL, SELAI DAN KERUPUK DI DESA ILODULUNGA KECAMATAN ANGGREK KABUPATEN GORONTALO UTARA
}

\author{
Selvi ${ }^{1)}$, Sri Indriyani Seme Dai ${ }^{2)}$ \\ Fakultas Ekonomi, Universitas Negeri Gorontalo \\ Email: Evinani80@gmail.com \\ Fakultas Ekonomi, Universitas Negeri Gorontalo \\ Email:indriyanidaiseme24@gmail.com
}

\begin{abstract}
This Community Service of Learning and Community Empowerment activity (Henceforth called by KKN-PPM) is entitled by Development of Production Business Unit and Packaging of Seaweed Based Processed Product for Micro Enterprise of Making Dodol (Typical Indonesian sweet toffee-like sugar palm-based confection), Selai (Jam) and Kerupuk (Typical Indonesian cracker) and it takes place in Village of Ilodulunga, Sub-district of Anggrek which is base of seaweed farmers in District of Gorontalo Utara. KKN-PPM activity aims to guide and to empower group of seaweed farmers thus the society has knowledge and skill in processing seaweed to be processed food product which has high economic value through utilization of appropriate technology, thus it is able to improve income of seaweed farmers. Generally, program achievement can be seen from implementation of the program in type of training and guidance for enterprise group that produces seaweed to be products of dodol, selai and kerupuk which is finished based on the plan. Based on finding of monitoring and evaluation performed either by KKN-PPM team or Research and Community Service Institution (LPPM) of Gorontalo State University, it can be concluded that the activity is well applied and succeeded. This refers to target and output, thus it can be measured through the expected indicators of program achievement from KKNPPM products namely: a) improvement of Production: It is improved, response of the groups is positive towards the activity. Expectation of the groups continues to other activity stages which can be developed, particularly through improvement of KKN-PPM team production to grant various tools/ equipments which support the production process; b) Cost Efficiency: By utilizing proper technology, the enterprise group society in producing seaweed processed product such as dodol, selai and kerupuk is easier which is supported by adequate tools/equipments; c) System Repair: The system repair in enterprise group of seaweed processor to be processed product such as dodol, selai and kerupuk have been improved and it is able to be implemented through training to enterprise group about how to shape good entrepreneurship sense and the management thus every enterprise is difficult to have loss; $d$ ). Improvement of Society Participation: The improvement of society participation towards enterprise group about how to process the seaweed to be nutritious food as dodol, selai and kerupuk has been improved. This can be seen from other society involvement in making dodol, selai and kerupuk. Therefore, it is expected to decrease unemployment level and improve household income.
\end{abstract}

Keywords: Production Process, Packaging, Seaweed 


\section{PENDAHULUAN}

Provinsi Gorontalo merupakan salah satu Provinsi utama penghasil rumput laut di Indonesia. Dari 6 (enam) Kabupaten/Kota yang ada di Provinsi Gorontalo, konsentrasi usaha budidaya rumput laut tersebar di 3 (tiga) Kabupaten yakni Kabupaten Boalemo, Kabupaten Pohuwato dan Kabupaten Gorontalo Utara. Untuk Kabupaten Gorontalo Utara salah satu sentra utama produksi rumput laut terletak di Kecamatan Anggrek khususnya di Desa Ilodulunga yang terletak di pesisir pantai. Mata pencaharian utama penduduk di Desa Ilodulungga adalah sebagai nelayan dan khusus untuk budidaya rumput laut diusahakan secara berkelompok. Kelompok nelayan pembudidaya rumput laut yang ada saat ini sebanyak empat kelompok nelayan pembudidaya rumput laut yang ada saat ini sebanyak empat kelompok dengan jumlah anggota setiap kelompok sebanyak 10 orang.

Berdasarkan data yang berhasil diperoleh dari lapangan, jumlah produksi rumput laut di Desa Ilodulungga rata-rata sebanyak 50-60 ton pertahun.Dengan demikian rata-rata produksi setiap kelompok selama satu tahun adalah sebanyak 12-15 ton pertahun.Dengan harga pasar rumput laut kering saat ini sebesar 15.000/kg maka potensi penghasilan perkelompok seharusnya sebesar 180 juta-225 juta pertahun.Dengan jumlah anggota kelompok sebanyak 10 orang maka rata-rata potensi pendapatan setiap anggota sebesar 18 juta-22.5 juta pertahun. Potensi pendapatan ini akan jauh lebih tinggi lagi jika produksi rumput laut di jual dalam bentuk olahan.

Namun sayangnya, tingginya potensi pendapatan tersebut tidak dapat dinikmati sepenuhnya oleh masyarakat.Hal ini dikarenakan oleh harga jual rumput laut di tingkat petani ditentukan oleh tengkulak atau pedagang pengumpul.Fenomena ini disebabkan oleh rendahnya posisi tawar petani sehingga mereka terpaksa menerima harga yang ditentukan oleh tengkulak.Rendahnya posisi tawar ini disebabkan oleh ketiadaan akses pasar kerena ketidaktahuan petani. Rendahnya posisi tawar ini semakin diperparah dengan adanya sebagian petani yang meminjam modal usaha kepada tengkulak yang akan dibayar dengan hasil produksi sehingga tengkulak akan semakin bebas dalam menentukan harga beli rumput laut.

Fenomena lain yang diamati dilapangan adalah ketidakmampuan petani dalam memanfaatkan panen rumput laut yang melimpah tersebut. Ini terlihat dari bentuk penjualan rumput laut yang sebagian besar masih berupa bahan mentah berupa rumput laut basah maupun kering.Usaha pengolahan rumput laut menjadi produk olahan makanan juga sudah dilakukan namun masih berskala kecil dan tidak bersifat kontinu.Pengolahan rumput laut dilakukan hanya jika terdapat sisa produksi yang tidak diserap oleh tengkulak atau pedagang pengumpul. Area pemasaran produk bahan makan yang dihasilkan juga masih disekitar masyarakat desa sehingga permintaan yang ada masih relatif kecil

Berdasarkan fenomena tersebut di atas maka melalui program KKN-PPM kami sebagai staf pengajar Universitas Negeri Gorontalo mencoba memformulasikannya ke dalam program KKNPPM dengan harapan beroleh bantuan pembiayaan.Sehingga dengan program KKNPPM kami staf pengajar mencoba melakukan transfer ilmu dan teknologi kepada masyarakat pengguna melalui keterlibatan mahasiswa secara langsung. Mahasiswa sejumlah 30 orang akan hidup berdampingan dengan penduduk untuk secara bersama melakukan kegiatan praktek dalam rangka penyelesaian masalah yang dihadapi selama ini. Transfer ilmu dan teknologi tersebut akan melibatkan staf dosen, mahasiswa, penyuluh lapangan dan penduduk Beberapa alat peraga akan diadakan melalui kegiatan KKNPPM ini sebagai wujud bantuan untuk membantu proses produksi.

\section{Usulan Penyelesaian Permasalahan}

Untuk menyelesaikan beberapa masalah yang diuraikan di atas diusulkan beberapa langkah penyelesaian permasalahan sebagai berikut:

1. Pelatihan peningkatan kualitas pengolahan hasil rumput laut menjadi produk makanan olahan yakni dodol, selei dan kripik rumput laut. Pelatihan difokuskan pada proses produksi dengan maksud agar hasil produk makanan olahan yang dihasilkan oleh kelompok masyarakat lebih berkualitas dari segi kebersihan dan lebih higenis. Tujuannya 
adalah agar produksi yang dihasilkan lebih muda ditawarkan ke masyarakat umum.

2. Peningkatan kualitas produksi pasca produksi yang dimaksudkan untuk memperbaiki posisi tawar produk yang dihasilkan. Pendampingan yang dilakukan berupa pelatihan pengemasan meliputi desain kemasan, diversifikasi kemasan, dan pengurusan izin produk. Tujuan pendampingan ini agar produk olahan yang dihasilkan mampu mempunyai positioning di pasar dan mampu melakukan branding kerena telah memiliki ciri tertentu yang ditampilkan dalam kemasan. Pelatihan dalam tahap ini akan melibatkan narasumber yang memiliki pengalaman serta dari lembagalembaga yang bersesuaian seperti BPPOM, Akademisi, Dinas Koperasi dan Perindustrian dan pihak-pihak yang terkait lainnya.

3. Setelah pendampingan terhadap proses produksi dan pengemasan dilakukan maka tahapan selanjutnya akan dilakukan pendampingan dalam hal pemasaran produk. Bentuk pendampingan berupa pelatihan teknik pemasaran sederhana yang dapat diterapkan oleh masyarakat. Pelatihan ini akan melibatkan akademisi yang mempunyai pengalaman dan latar belakang manajemen pemasaran dari Universitas Negeri Gorontalo.

4. Setelah pendampingan terhadap proses pemasaran produk tahapan selanjutnya akan dilakukan pendampingan berupa pelatihan pencatatan keuangan usaha yang baik. Pelatihan ini akan melibatkan akademisi yang mempunyai pengalaman dan latar belakang manajemen keuangan dari Universitas Negeri Gorontalo.

Adapun keberlanjutan program akan ditentukan oleh pola kinerja mahasiswa dalam pelaksanaan kegiatan KKN-PPM. Penempatan mahasiswa pada semua program kegiatan adalah dalam rangka memetakan potensi dan masalah yang mungkin muncul serta solusi dan alternatifnya.Bantuan teknologi memasak, pengemasan dan penyimpanan adalah upaya meningkatkan efisiensi dan efektifitas proses pengolahan. Keberadaan bantuan ini akan meningkatkan kinerja produksi dan pengolahan yang dilakukan oleh kelompok sasaran. Proses pemasaran akan dilakukan oleh mahasiswa dengan melibatkan masyarakat desa di Ilodulunga dan akan didistribusikan kelembaga-lembaga mitra dan toko-toko yang ada di kabupaten Gorontalo Utara dan Gorontalo sekitarnya. Sehingga setelah program selesai akan diperoleh pemetaan pasar bagi produk yang dihasilkan sehingga menghilangkan sistem tengkulak / para penghijon. Pangsa pasar ini akan di lakukan prospektifnya oleh mahasiswa peserta KKNPPM. Dengan pangsa pasar yang terpola selama program berlangsung maka peluang keberlanjutan program akan sangat besar dan menjanjikan.

\section{Teknologi/Metode/Kebijakan/Konsep yang akan digunakan untuk mengatasi permasalahan}

Guna mendukung program tersebut ada beberapa hal yang ditawarkan untuk mengatasi permasalahan tersebut di atas diantaranya adalah sebagai berikut:

1. Memperkenalkan teknologi yang dapat digunakan dalammendifersifikasi produk makanan olahan rumput laut menjadi olahan makanan yang berkualitas seperti Dodol, Selei dan Kerupuk. Adapun teknologi yang digunakan adalah berupa mesin pembuat dodol, selei dan kerupuk, sehingga melalui penggunaan teknologi mesin tersebut diharapakan masyarakat di Desa Ilodulunga mampu menghasilkan Dodol,Selei dan kerupuk yang higenis dan sehat, serta dapat menghasilkan produksi yang lebih banyak dengan menggunakan tenaga-tenaga manual, disamping itu juga memberikan sentuhan teknologi pada pembuatan kemasan dari ketiga produk makanan hasil olahan rumput laut sehingga memiliki daya tarik untuk dibeli oleh para konsumen.

2. Metode yang digunakan dalam melakukan peningkatan dan pemberdayaan kelompok penghasil rumput laut untuk membuat bahan olahan makanan yaitu terlebih dahulu dilakukan pelatihan kepada kelompokkelompok penghasil rumput laut bagaimana menghasilkan produk olahan makanan dari rumput laut seperti Dodol,Selei dan Kerupuk, setelah itu dilakukan Bimtek untuk lebih memberikan pengetahuan tata cara 
membuat olahan makanan yang berbahan baku rumput laut serta bagaimana membuat kemasan yang menarik sehingga produk olahan makanan tersebut memiliki daya tarik bagi konsumen.

3. Menciptakan kebijakan sistem bapak angkat untuk usaha kelompok penghasil rumput laut menjadi olahan makanan seperti Dodol, Selei dan Kerupuk. Sehingga produk ini memiliki kesinambungan khususnya jangka panjang.

4. Memperkenalkan konsep manajemen modern dalam mengelola hasil olahan rumput laut sebagai usaha kelompok di Desa Ilodulunga Kecamatan Anggrek Kabupaten Gorontalo dalam rangka pemberdayaan dan peningkatan pendapatan masyarakat.

\section{Lembaga Mitra dan Kelompok Sasaran}

\section{Program KKN-PPM}

Adapun yang menjadi lembaga mitra pada kegiatan ini adalah Kelompok Usaha Fitrah Bersama yang beralamatkan di Desa Ilodulunga Kecamatan Anggrek Kabupaten Gorontalo Utara. Kelompok usaha Fitrah Bersama ini adalah kelompok usaha yang menyediakan bahan baku berupa rumput laut yang merupakan bahan dasar dari pembuatan produk olahan dodol, selei dan kerupuk. Lembaga mitra kedua dalah Pemerintah Desa Ilodulunga Kecamatan Anggrek Kabupaten Gorontalo Utarayang bertanggung jawab dalam hal pengawasan dalam proses kegiatan program KKN-PPM. Adapun yang menjadi kelompok sasarannya adalah masyarakat pembudidaya rumput laut

\section{Profil Kelompok Sasaran}

Kelompok sasaran program adalah kelompokmasyarakat pembudidya rumput laut yang bergerak pada usaha pengrajin budidaya rumput laut. Terdapat lima kelompok pembudidaya rumput laut yang tersebar pada lima kelompok.

Tabel 1.1.Nama kelompok dan Jumlah anggotanya

Desa Ilodulunga Kecamatan Anggrek Kabupaten Gorontalo Utara

\begin{tabular}{|l|l|c|}
\hline \multicolumn{1}{|c|}{$\begin{array}{c}\text { Nama } \\
\text { Kelompok }\end{array}$} & \multicolumn{1}{c|}{$\begin{array}{c}\text { Ketua } \\
\text { Kelompok }\end{array}$} & $\begin{array}{c}\text { Jumlah } \\
\text { Anggota }\end{array}$ \\
\hline Lestari I & Ledis Nurdin & 10 Orang \\
\hline Lestari 2 & $\begin{array}{l}\text { Adam } \\
\text { Dudunguo }\end{array}$ & 10 Orang \\
\hline Melati & Raman Sikili & 10 Orang \\
\hline Erfak Star & Ismet Kasiati & 10 Orang \\
\hline
\end{tabular}

Kelompok sasaran dalam Program KKNPPM ini adalah masyarakat pembudidaya rumput laut, adapun potensi dan permasalahan dari kelompok sasaran adalah sebagai berikut:

Tabel 1.2. Kelompok Sasaran, Potensi dan Permasalahannya

\begin{tabular}{|c|c|c|}
\hline Kelompo & Potensi & Permasalahan \\
\hline $\begin{array}{l}\text { Masyarak } \\
\text { at } \\
\text { pembudid } \\
\text { aya } \\
\text { rumput } \\
\text { laut }\end{array}$ & $\begin{array}{l}\text { Adanya } \\
\text { prakars } \\
\text { a } \\
\text { masyara } \\
\text { kat } \\
\text { untuk } \\
\text { mengol } \\
\text { ah } \\
\text { rumput } \\
\text { laut } \\
\text { menjadi } \\
\text { olahan } \\
\text { makana } \\
\text { n yang } \\
\text { bernilai } \\
\text { ekonom } \\
\text { i } \\
\\
\text { Rumput } \\
\text { laut } \\
\text { menjadi } \\
\text { bahan } \\
\text { baku } \\
\text { untuk } \\
\text { produk } \\
\text { makana } \\
\text { n }\end{array}$ & $\begin{array}{l}\text { Keterbatasan } \\
\text { pengetahuan } \\
\text { dan } \\
\text { ketrampilan } \\
\text { dalam } \\
\text { mengolah } \\
\text { rumput laut } \\
\text { menjadi bahan } \\
\text { olahan } \\
\text { makanan yang } \\
\text { berkualitas. } \\
\text { Upaya } \\
\text { pengolahan } \\
\text { menjadi produk } \\
\text { pangan seperti } \\
\text { dodol, selei dan } \\
\text { kerupuk } \\
\text { menemui } \\
\text { kendala teknis, } \\
\text { baik dari segi } \\
\text { mutu, dan } \\
\text { kemampuan } \\
\text { diversifikasi } \\
\text { produk }\end{array}$ \\
\hline $\begin{array}{l}\text { Masyarak } \\
\text { at } \\
\text { pembudid } \\
\text { aya }\end{array}$ & $\begin{array}{l}\text { - Adanya } \\
\text { kepedul } \\
\text { ian } \\
\text { masyara } \\
\text { kat }\end{array}$ & $\begin{array}{l}\text { Proses produksi } \\
\text { (memasak) } \\
\text { yang memakan }\end{array}$ \\
\hline
\end{tabular}




\begin{tabular}{|c|c|c|}
\hline $\begin{array}{l}\text { rumput } \\
\text { laut }\end{array}$ & $\begin{array}{l}\text { pembud } \\
\text { idaya } \\
\text { rumpu } \\
\text { laut } \\
\text { untuk } \\
\text { selalu } \\
\text { mening } \\
\text { katkan } \\
\text { mutu } \\
\text { dan } \\
\text { keaman } \\
\text { an } \\
\text { produk }\end{array}$ & $\begin{array}{l}\text { waktu yakni } 5 \\
\text { hari } \\
\text { - } \text { Kemasan yang } \\
\text { masih } \\
\text { tradisonal yakni } \\
\text { masih } \\
\text { menggunakan } \\
\text { pelastik gula } \\
\text { pasir } \\
\text { - Pemasaran hasil } \\
\text { yang kuran } \\
\text { lancar dan } \\
\text { kurang } \\
\text { menguntungkan }\end{array}$ \\
\hline $\begin{array}{l}\text { Masyarak } \\
\text { at } \\
\text { pembudid } \\
\text { aya } \\
\text { rumput } \\
\text { laut }\end{array}$ & $\begin{array}{l}\text { Adanya } \\
\text { keterbu } \\
\text { kaan } \\
\text { masyara } \\
\text { kat } \\
\text { pembud } \\
\text { idaya } \\
\text { rumput } \\
\text { laut atas } \\
\text { kesulita } \\
\text { n yang } \\
\text { dihadap } \\
\text { i dan } \\
\text { terus } \\
\text { mencari } \\
\text { solusi } \\
\text { untuk } \\
\text { bisa } \\
\text { memen } \\
\text { uhi } \\
\text { standar } \\
\text { agar } \\
\text { bisa } \\
\text { terterim } \\
\text { a oleh } \\
\text { konsum } \\
\text { en }\end{array}$ & $\begin{array}{l}\text { - Pengetahuan } \\
\text { masyarakat } \\
\text { pembudidaya } \\
\text { rumput laut } \\
\text { terhadap } \\
\text { penggunaan } \\
\text { teknologi atas } \\
\text { produk seperti: } \\
\text { teknologi } \\
\text { proses } \\
\text { pengolahan, } \\
\text { model produk, } \\
\text { serta kemasan } \\
\text { produk. } \\
\text { Keterbatasan } \\
\text { pengetahuan } \\
\text { tentang sanitasi, } \\
\text { pengolahan } \\
\text { untuk } \\
\text { menghasilkan } \\
\text { produk yang } \\
\text { higienis. }\end{array}$ \\
\hline
\end{tabular}

\section{TARGET DAN LUARAN}

\section{Tujuan}

Tujuan utama dari kegiatan KKN-PPM

adalah untuk memberikan pengalaman mahasiswa dalam keikutsertaanya dalam proses pembangunan. Melalui kegiatan ini diharapkan akan membuka wawasan mahasiswa, serta dapat dijadikan sebagai saranan dalam proses pendewasaan berfikir, bertindak dan mengambil keputusan terhadap sesuatu yang akan atau telah direncanakan. Secara eksplisit, tujuan yang hendak dicapai dengan dilaksanakannya program KKN-PPM adalah sebagai berikut:

- Mengarahkan pengetahuan dan keterampilan serta keilmuan dosen dan mahasiswa untuk membuktikannya dalam menangani permasalahan masyarakat dengan memberikan solusi penyelesaian masalah.

- Memberikan pengalaman belajar tentang sosial masyarakat dan pengalaman dalam pembangunan

- Menumbuhkan kepercayaan masyarakat akan kemampuan mahasiswa serta, sehingga akan lebih mendekatkan Universitas Negeri Gorontalo pada masyarakat

\section{Target dan Luaran}

Kegiatan KKN-PPM ini membawa misi untuk membina dan memberdayakan kelompok masyarakat pembudidaya rumput laut. Melalui program ini baik dosen dan mahasiswa dapat mengaplikasikan pengetahuan, ilmu dan keterampilan maupun teknologi untuk menagani kekurangan dan masalah yang dihadapi oleh para mahasiswa untuk dapat berinteraksi dan bekerja sama dengan masyarakat. Pada program ini yang fokus pada bidang usaha diharapkan akan dapat meningkatkan pendapatan para pembudidaya rumput laut.

Adapun indikator capaian produk program KKN-PPM yang dituju adalah sebagai berikut:

1. Peningkatan produksi

Pada umumnya masyarakat pembudidaya rumput laut dalam memproduksi olahan rumput laut menjadi produk olahan bahan makan yaitu dodol,selei dan kerupuk yang berbahan baku rumput laut hanya sebatas pengolahan secara tradisional, masingmasing kelompok melakukan proses produksi hanya sesuai kebutuhan konsumsi masyarakat sehingga belum memenuhi peningkatan pendapatan masyarakat di desa Ilodulunga tersebut. Dengan pelaksanaan KKN-PPM ini diharapkan akan memberdayakan masyarakat pembudidaya rumput laut menggunakan 
Perbaikan teknologi melalui bantuan alat memasak, kuali/wajan, plastik kemasan, mal cetakan produk. sehingga diperoleh efisiensi dan efektivitas proses produksi dan kemasan.Sehingga dapat meningkatkan pendapatan masyarakat di desa tersebut.

2. Efesiensi Biaya

Dengan memanfaat teknologi yang tepat guna masyarakat pembudidaya rumput laut dalam menghasilkan olahan makan berupa dodol, selei dan kerupuk dapat menekan efesiensi biaya melalu meningkatkan hasil budidaya rumput laut yang menjadi bahan baku utama pembuatan produk olahan makan tersebut, disamping itu kelompok pembudidaya rumput laut harus memberdayakan kelompok-kelompok yang sudah ada untuk bagaimana menghasilkan produk makanan rumput laut tersebut sehingga menekan biaya tenaga kerja yang besar.

3. Perbaikan Sistem

Melalui Program KKN-PPM ini diharapkan dapat memperbaiki sistem di dalam kelompok masing-masing pembudidaya rumput laut melalui perkenalan konsep manajemen moderen dalam mengelolah hasil olahan rumput laut sehingga kelompok-kelompok pembudidaya rumput laut tersebut dapat berkembang kesektor usaha kecil. Selain itu menciptakan sistem bapak angkat sehingga usaha-usaha kelompok tersebut dapat berkesinambungan.

4. Peningkatan Partisipasi Masyarakat

Dengan adanya peran anggota masyarakat dalam kegiatan pembudidayaan rumput laut mulai dari pembudidayaan rumput laut sampai dengan pengolahan rumput laut menjadi produk makanan seperti dodol, selei dan keripik diharapkan dapat meningkatkan partisipasi masyarakat agar semakin banyak masyarakat tertarik untuk membuat dan mengembangkan rumput laut. Dengan terlibatnya anggota masyarakat lain dalam membuat dan mengolah rumput laut menjadi produk olahan makanan yang berkualitas dan berdaya guna diharapkan akan mampu mengurangi tingkat pengangguran

5. Peningkatan Swadana dan Swadaya

Masyarakat atau PEMDA

Dalam pelaksanaan KKN-PPM diharapkan masyarakat mampu berpartisipasi baik moril maupun materil, disamping itu pemerintah diharapkan memberikan bantuannya berupa kebijakan dalam hal kegiatan kemasyarakatan dan pembagunan terutama dalam mendukung kegiatan KKN-PPM tersebut.

\section{PEMBAHASAN}

Program pelaksanaan KKN-PPM yang dilakukan oleh Lembaga Penelitian Dan Pengabdian Masyarakat Universitas negeri Gorontalo merupakan kegiatan pemberdayaan kepada masyarakat yang akan melahirkan mahasiswa yang memiliki empati dan peduli terhadap permasalahan masyarakat ekonomi lemah dan mampu memberdayakan mereka untuk menolong diri mereka sendiri sehingga memiliki taraf hidup yang lebih baik. Sesuai dengan prinsip-prinsip KKN-PPM yakni:

1. Keterpaduan aspek Tri Dharma Perguruan Tinggi, Apek pendidikan dan pengajaran, dan pengabdian kepada masyarakat yang berbasis penelitian menjadi landasan dalam perencanaan, pelaksanaan dan tolak ukur evaluasi KKN-PPM.

2. Empati-Partisipatif,

KKN-PPM dilaksanakan untuk menggerakan masyarakat pembagunan melalui berbagai kegiatan yang dapat melibatkan, mengikutsertakan, menumbuhkan rasa memiliki masyarakat terhadap pembangunan, KKN-PPM dilaksanakan secara interaktif dan sinergis antara mahasiswa dan masyarakat. Konsekuensinya, keterlibatan kedua belah pihak dalam setiap kegiatan mutlak diperlukan, keterlibatan tersebut dimulai sejak perencanaan program kegiatan lapangan, pelaksanaan dan pengusahaan pendanaan. Untuk itu para mahasiswa dan pengelolah KKN-PPm harus mampu mengadakan pendekatan sosio-kultur terhadap masyarakat sehingga lebih kooperatif dan partisipatif. 
3. Interdisiplineer, KKN-PPM dilaksanakan oleh mahasiswa yang berasal dari berbagai disiplin ilmu di lingkungan universitas dan pelaksanaannya dikoordinasikan oleh LPPM. Dalam operasionalnya mahasiswa mengembangkan mekanisme pola pikir dan pola kerja interdisipliner untuk memecahkan permasalahan yang ada dilokasi KKN-PPM.

4. Komprehensif-Komplementatif dan berdimensi

KKN-PPM berfungsi sebagai pengikat,perangkum, penambah dan pelengkap kurikulum yang ada. Dengan demikian diharapkan mahasiswa peserta KKN-PPM mampu mengatualisasikan diri secara profesional dan proporsional.

5. Realistis-Pragmatis

Program-program kegiatan yang direncanakan pada dasarnya bertumpuh pada permasalahan dan kebutuhan nyata dilapangan, dapat dilaksanakan sesuai dengan daya dukung sumber daya yang tersedia dilapangan dan memberikan manfaat bagi masyarakat, baik jangka pendek maupun jangka panjang.

6. Environmental development

Dilaksanakan untuk melestarikan dan mengembangkan lingkungan fisik dan sosial untuk kepentingan bersama.

Berdasarkan prinsip-prinsip tersebut diharapkan mahasiswa peserta KKN-PPM mampu mengidentifikasi permasalahan yang ada di masyarakat dan mencari penyelesaiannya sesuai dengan sumber daya yang dimiliki, dengan harapan, masyarakat mampu berswadaya, berswakelola dan berswadana dalam pembangunan. Pelaksanaan KKN-PPM yang telah dilakukan selama ini sangat bermanfaat dalam peningkatan perekonomian masyarakat di desa Ilodulunga secara khusus dan masyarakat Kecamatan Anggrek Pada Umumnya, yang dilakukan melalui program-program yang telah diberikan kepada masyarakat terutama pada program pemberdayaan kelompok usaha pembudidaya rumput laut, yang pada awalnya mereka menjual hasil panen rumput laut kering yang harganya cukup murah. Namun setelah dilakukan Pemberdayaan melalui pelatihan dan pendampingan bagi kelompok usaha pengolahan rumput laut menjadi olahan beraneka ragam panganan yang dapat memberikan pendapatan yang lebih besar bagi masyarakat tersebut. Dan kegiatan tersebut selesai dilaksanakan sesuai dengan perencanaan.

Berdasarkan hasil monitoring dan evaluasi yang dilakukan baik tim KKN-PPM maupun oleh lembaga Penelitian dan Pengabdian Masyarakat (LPPM) Universitas Negeri Gorontalo dapat disimpulkan bahwa kegiatan ini dapat berjalan dengan baik dan sukses. Hal ini mengacu pada target dan luaran program yang tercantum pada Bab 2 maka dapat diukur melalui indikator capaian program dari produk $\mathrm{KKN}$ PPM yang hendak ditujuh sebagai berikut:

1) Peningkatan produksi

Peningkatan produksi sudah mengalami peningkatan, respon para peserta kelompok usaha sangat positif terhadap kegiatan tersebut. Harapan para peserta kelompok usaha kegiatan tersebut dapat berlanjut pada tahapan-tapan kegiatan yang lain yang dapat dikembangkan. Terutama melalui pengikatan produksi tim KKN-PPM menyumbangkan berbagai macam alat yang akan mendukung proses produksi tersebut.

2). Efesiensi Biaya

Dengan memanfaat teknologi yang tepat guna masyarakat kelompok usaha dalam menghasilkana produk olahan panganan rumput laut seperti dododl, selai dan kerupuk sudah lebih muda karna di dukung oleh peralatan yang lebih memadai.

3). Perbaikan Sistem

Perbaikan sistem dalam masyarakat kelompok usaha pengolah rumput laut menjadi panganan berupa dodol, selai dan kerupuk, sudah mengalami perbaikan ini dapat diwujudkan dengan melakukan pelatihan kepada kelompok usaha bagaimana membetuk jiwa wirausaha yang baik dan bagaimana melakukan manajemen usaha sehingga setiap usaha yang telah dibuat tidak mudah mengalami kerugian

4). Peningkatan Partisipasi Masyarakat

Peningkatan partisipasi masyarakat terhadap kegiatan kelompok usaha bagaimana mengolah rumput laut menjadi panganan yang bergizi berupa dodol,selai dan kerupuk sudah mengalami peningkatan. Hal ini dapat 
dilihat dari keterlibatan masyarakat lain dalam membuat dodol, selai dan kerupuk. Sehingga hal tersebut diharapkan mampu mengurangi tingkat pengangguran dan mampu meningkatkan pendapat rumah tangga.

\section{Habatan Pelaksanaan dan Upaya Perbaikan}

Pelaksaanaan program KKN-PPM ini meskipun sudah ditunjang dengan pembiayaan yang memadai namun ada saja hambatan dalam pelaksanaannnya. Maka oleh karena itu hambatan dan upaya perbaikannya parlu diuraikan sebagai berikut:

\section{Hambatan:}

1. Belum adanya akses pemasaran terhadap produk yang dihasilkan oleh kelompok usaha

2. Belum adanya uji kelayakan akan ketiga jenis produk panganan sehingga belum bisa ditetapkan massa kada luarsa produk pangan tersebut.

3. Belum terselesaikan sertifikat Pangan Industri Rumah Tangga (PIRT) dari dinas kesehatan dan standarisasi produk dari BPOM dikarenakan keterbatas waktu dalam pelaksanaan KKN-PPM

Upaya Mengatasi:

1. Permasalahan akses pemasaran yang menjadi hambatan oleh kelompok usaha diharapkan mampu melakukan kerjasama dengan pemerintah desa melalui peran dan fungsi BUMDES dalam mencarikan solusi bagaimana memasarkan hasil olahan kelompok usaha sehingga produk-produk dodol, selai dan kerumpuk rumput laut dapat dipasarkan

2. Berupaya mnendorong, memotivasi dan merekomendasikan melalui pemerintah desa agar kiranya dapat menindak lanjuti pengurusan sertifikat PIRT dan BPOM terkait produk dodol, selai dan kerupuk sehingga kedala pemasaran terhadap produk dapat terselesaikan dengan baik.

\section{Keberlanjutan Program}

Indikator keberlanjutan program dapat diukur melalui keberhasilan tim peserta KKNPPM dan peserta KKN-PPM dalam mensukseskan kegiatan dan program yang sudah direncanakan. Selain itu kelompok usaha yang sudah mendapatkan pelatihan dan bimbingan teknik mampu mempraktekan apa yang sudah diberikan sehingga dapat dikembangkan pada usaha masing-masing dan dapat memberikan dampak perubahan yang baik, yang dapat dilihat dari hasil olahan produk dodol, selai dan kerupuk yang dihasilkan oleh kelompok usaha tersebut. Dal hal tersebut pada akhirnya bermuara pada peningkatan pendapatan ekonomi keluarga khususnya masyarakat di desa Ilodulunga dan umumnya masyarakat Kecamatan Anggrek Kabupaten Gorontalo Utara.

\section{KESIMPULAN DAN SARAN KESIMPULAN}

Mengaju pada target dan luaran program KKN-PPM maka dapat ditarik satu kesimpulan sebagai berikut:

1. Pelaksanaan program KKN-PPM dapat membantu masyarakat dalam hal ini di desa Ilodulunga Kecamatan Anggrek Kabupaten Gorontalo Utara untuk meningkatkan pendapatan ekonomi mereka melalui pemberdayaan masyarakat kelompok usaha pembudidayaa rumput laut dalam memanfaatkan rumput laut menjadi panganan yang beraneka ragam berupa dodol, selai dan kerupuk yang berkualitas.

2. Melalui pelaksanaan program KKN-PPM sangat membatu masyarakat di Desa Ilodulungga Kecamatan Anggrek Kabupaten gorontalo Utara dalam hal peningkatan produksi melalui aspek produksi, aspek pemasaran dan aspek manajemen usaha.

3. Adapun hambatan yang dihadapi oleh masyarakat dalam hal ini kelompok usaha dodol, selai dan kerupuk secara bertahap dapat diselesaikan oleh tim melalui pelaksanaan program kegiatan KKN-PPM.

\section{SARAN}

Adapun saran yang dapat disajikan dalam pelaksanaan program KKN-PPM sebagai berikut

1. Untuk menjaga keberlanjutan program ini agar kiranya pelaku usaha yang sudah mendampatkan pelatihan dan pendampingan selalu mendapatkan perhatian baik dari pemerintah desa 
Ilodulunga maupun pemerintah Kabupaten Gorontalo utara. Sehingga produktivitas para pelaku usaha tidak hanya pada proses kegiatan KKN-PPM namun terus berkesinambungan dan dapat bekerja sama dengan Badan Usaha Milik Desa.

2. Adanya dukungan pemerintah Kabupaten Gorontalo utara melalui Dinas Perindustrian dan Dinas Kesehatan dalam hal pengurusan izin dan dokumen lainnya yang mendukung kelancaran oprasional dan pemasaran bagi kelompok usaha dodol, selai dan kerupuk

\section{DAFTAR PUSTAKA}

Anggadiredja, J.T, Achmad Z, Heri P, Sri

A.2006. Rumput Laut.

Penebar Swadaya. Jakarta.Armin S. 1999.

Gorontalo dalam angka, 2013.

Petunjuk Teknis Budidaya Rumput Laut. Dinas Perikanan Kabupaten Pinrang, PinrangDwi Djoseputro. 1988.

Susanti Sako, 2015. Gorontalo akan kembangkan budidaya rumput laut. Antara New 